\title{
KEMAMPUAN PROFESIONAL GURU DAN KEMAMPUAN AKEDEMIK DOSEN DALAM UPAYA PENINGKATAN RELEVANSI DAN MUTU PENDIDIKAN NASIONAL
}

\author{
Soedijarto
}

Abstract

It is strongly believed that teacher's professional competence and lecturer's academic competence play significant role in improving the relevance and the quality of national education. This article therefore discusses teacher as a professional job and the reasons why the teachers must be professional in this 21st century, the program of teacher provision, lecturer as an academic human resource at higher education, and the financial implication of the teacher as professional job and the lecturers of higher education as scientific instructors. To end the article some notes on the problems discussed are presented in details.

Kata kunci: kemampuan profesional; kemampuan akademik; mutu pendidikan

\section{PENDAHULUAN}

Saat ini kita masih dihadapkan kepada tuntutan agar guru kita dari SD sampai SLTA memiliki kemampuan profesional agar mampu melaksanakan pendekatan baru dalam penyelenggaraan pendidikan, yaitu kurikulum berbasis kompetensi (KBK) dan kaitannya dengan dosen sebagai tenaga akademik. Baik penerapan pendekatan PPSI maupun KBK keduanya bertujuan agar pendidikan kita tambah relevan dan bermutu sesuai dengan tuntutan perkembangan masyarakat. Dengan demikian makalah ini akan membahas mengenai: (1) Guru sebagai jabatan profesional dan mengapa guru di abad ke-21 ini harus bertaraf profesional?; (2) program pengadaan guru (pendidik) dan tenaga kependidikan; (3) dosen sebagai tenaga pendidik akademik dan persyaratannya; dan (4) implikasi pembiayaan bagi pengadaan tenaga guru profesional dan tenaga dosen sebagai tenaga akademik (ilmuwan pengajar).

\section{PEMBAHASAN}

I. Mengapa guru di abad ke-21 harus profesional?

Kalau kita menajajaki sejarah pendidikan Indonesia, kita akan mendapatkan pengetahuan bahwa kualifikasi guru yang mengajar di SD, SLTP, dan SLTA pada zaman penjajahan, dan zaman Indonesia merdeka samapi dengan tahun terakhir dekade 1950-an dan permulaan dekade 1960-an jauh dibawah kualifikasi guru pada saat ini. Pada zaman penjajahan Belanda, pendidikan guru SD 3 tahun (Sekolah Desa) adalah CVO (2 tahun setelah SD), pendidikan guru SD Nomor dua (SD 5 tahun) adalah Normal School (4 tahun setelah lulus SD), untuk HIS (Sekolah Dasar Belanda untuk orang Indonesia dengan bahasa pengantar bahasa Belanda yang lamanya 7 tahun) adalah HIK (6 tahun setelah HIS) dan untuk SMP (MULO) adalah Hooftakte (Kursus seperti PGLSP), praktek ini berlanjut setelah Indonesia merdeka. Sampai dengan tahun 1957 pendidikan guru SD adalah Sekolah Guru B (SGB - 4 tahun setelah SD), guru SMP adalah SGA (6 tahun setelah SD atau 3 tahun setelah SMP/SGB kelas III), dan guru SLTA adalah B I (2 tahun setelah SMA). Setelah tahun 1957 guru SD haruslah lulusan SGA. Pada saat itu Perguruan Tinggi Pendidikan Guru (PTPG) belum menghasilkan lulusannya.

Kini, terutama sejak tahun 1989 kualifikasi minimum untuk mengisi jabatan guru ditingkatkan yaitu untuk guru SD adalah Diploma II Kependidikan (2 tahun pasca SLTA), untuk guru SLTP adalah D3 kependidikan (3 tahun pasca SLTA), dan untuk guru SLTA adalah S1 kependidikan dan S1 dengan Akta Mengajar (Akta IV). Pertanyaannya mengapa pada masa penjajahan dan permulaan kemerdekaan, guru dengan kualifikasi pendidikan yang jauh lebih rendah dari kualifikasi pendidikan guru pada saat ini dipandangan telah berhasil menghasilkan lulusan yang "bermutu" sedangkan sekarang dengan kualifikasi pendidikan yang lebih tinggi banyak dipersoalkan mutu dari pendidikan yang dihasilkan.

Memang tidak proporsional membandingkan mutu pendidikan pada tahun 1950-an dengan mutu pendidikan pada tahun 1989 keatas. Karena jumlah peserta didik pada dua periode tersebut perbedaannya berlipat. Murid SD pada tahun 1955 sebanyak 7.113 .456 orang, tahun 1989/1990 berjumlah 19.296.714. Siswa SLTP pada tahun 1955 berjumlah 
197.189 orang, kemudian pada tahun 1989/1990 jumlah siswa SLTP 13.672.438. Sementara siswa SLTA pada tahun 1955 berjumlah 103.267 orang, sedangkan pada tahun 1989/1990 berjumlah 4.338 .386 orang. Disamping itu sekolah pada waktu itu pendidikan mengutamakan fungsi memilah dan memilih dari pada mengembangkan potensi peserta didik. Karena itu banyak SD yang hanya berhasil meluluskan murid kelas VI-nya sekitar 10\%, demikian juga SLTP dan SLTA. Sedangkan pada tahun 19890-an pada saat telah dicanangkan wajib belajar pendidikan dasar 6 tahun dan dirancang wajib belajar pendidikan dasar 9 tahun, fungsi sekolah seyogyanya tidak hanya menseleksi melainkan dan terutama adalah mengembangkan kemampuan peserta didik. Karena itu tidak dapat diterima kalau banyak murid SD dan SMP yang dinyatakan tidak lulus, karena sekolah harus menyediakan tempat bagi anak-anak baru yang jumlahnya berlipat dan harus ditampung. Disinilah letak masalahnya, peranan guru pada saat melayani jumlah murid yang sedikit dan peranan sekolah yang terutama adalah memilah dan memilih, tidak dapat disamakan dengan peranan guru, pada saat tugasnya adalah mengembangkan potensi peserta didik yang heterogen latar belakangnya, baik kemampuan dasar, sosial, ekonomi, dan budaya. Kenyataan baru inilah yang menjadikan jabatan guru dituntut menjadi jabatan profesional.

Di negara-negara maju, seperti Amerika Serikat dan Jerman, yang menjaidkan sekolah sebagai lembaga untuk mengembangkan potensi peserta didik secar optimal dan mengarahkannya sesuai dengan kemampuan dasar, bakat, dan minatnya telah lama menjadikan jabatan guru sebagai jabatan profesional yang pendidikannya setara dengan pendidikan jabatan profesional lainnya, yaitu dokter dan pengacara.

Di abad ke-21 ini tidak ada negara di dunia ini yang tidak menerapkan wajib belajar, yang ada hanyalah penetapan wajib belajar antara satu negara berbeda dari negara lainnya. Ada negara yang menerapkan wajib belajar 12 tahun, seperti Amerika Serikat; ada negara yang menerapkan wajib belajar 10 tahun seperti Inggris dan Jerman; dan ada negara yang menerapkan wajib belajar pendidikan dasar 9 tahun, seperti Indonesia, disamping masih ada negara negara di Afrika dan Asia Selatan yang menerapkan wajib belajar pendidikan dasar 6 tahun.

Penerapan wajib belajar ini yang berani bahwa semua anak dengan perbedaan latar belakang baik kemampuan dasar kognitif, latar belakang sosial ekonomi dan minat serta bakat harus memperoleh pendidikan yang bermutu dan dilayani serta dapat berkembang sesuai dengan kemampuan, minat dan bakatnya.

Dalam pada itu diera globalisasi ini ilmu pengetahuan dan teknologi yang mcrupakan sumber bahan untuk dipelajari berkembang demikian cepat. Dalam kondisi yang demikian tuntutan terhadap kualitas manusia terdidik baik kemampuan intelektual, kemampuan vokasional dan rasa tanggung jawab kemasyarakatan, kemanusiaan dan kebangsaan juga meningkat sesuai dengan perkembangan masyarakat yang terus berubah dan meningkat tuntutannya kepada para warganya.

Heterogenitas peserta didik dalam berbagai dimensi (intelektual, kultural, dan ekonomi), terus berkembangnya ilmu pergetahuan dan teknologi sebagai sumber obyek belajar, terus berubahnva masyarakat dengan tuntutannya merupakan faktor yang menjadikan guru harus profesional. Karena itu peranan guru tidak lagi hanya memberikan pelajaran dengan ceramah atau mendikte tanpa memperhatikan perbedaan kemampuan, bakat dan minat peserta didik. Guru juga tidak dapat lagi menggunakan bahan pelajaran yang sudah ketinggalan jaman. Guru juga tidak dapat lagi hanya membantu peserta didik untuk dapat menjawab pertanyaan yang siftanya hafalan. Guru dalam era globalisasi perlu mampu merancang, memilih bahan pelajaran dan strategi pembelajaran (dalam bahasa KEK Sylabus) yang sesuai dengan anak dengan latar belakang yang berbeda, serta mengelola proses pembelajaran secara taktis dan menyenangkan, mampu memilih media belajar dan merancang program evaluasi yang sesuai dengan tujuan pendidikan yang berorientasi kepada penguasaan kompetensi.

Untuk itu perlu adanya upaya untuk meningkatkan pendidikan guru yang berderajat profesional. Dikatakan berderajat karena dalam setiap jabatan profesional dikenal hierarki profesional yaitu: profesional, semi profesional, teknisi, juru, dan tukang. Kalau dalam dunia kedokteran kita mengenal: tenaga dokter (profesional), para medik, yang lulusan Akademi sebagai semi profesional, yang lulusan SLTA sebagai teknisi (perawat) dan juru rawat. Di Amerika Serikat, guru, baik guru SD, guru SMP maupun SMA harus borpendidikan SI ditambah satu sampai dua tahun kuliah dan latihan keguruan untuk mendapat sertifikat guru. Di Jerman, untuk guru SD, harus berpendidikan"Paedagohische Hochshule" - 4 tahun setelah SMA, untuk guru (Gymnasium) dituntut pendidikan pada Fakultas Ilmu Pendidikan pada Universitas yang meliputi 6 semester untuk

Perspektif Ilmu Pendidikan - Vol. 13 Th. VII April 2006 
SD, SMP maupun SMA setelah lulus pendidikan di Perguruan Tinggi/Universitas tidak otomatis berwenang sebagai guru (certified teacher) melainkan harus melalui tahap magang selarna 18 bulan dan diakhiri dengan ujian kewenangan mengajar sebelum dapat memperoleh tanda sebagai guru yang berwenang.

Terilhami oleh praktek pendidikan calon guru didua ncgara tersebut, dan pengalaman menerapkan berbagai inovasi pendidikan dalam periode 1974 - 1981, say a pada tahun 1982 sampai kepada kesimpulan perlunya peningkatan jabatan guru sebagai jabatan profesional, suatu jabatan yang memerlukan pendidikan lanjut dan latihan khusus, yaitu SI plus.

Penerapan KBK hakekatnya sama dengan penerapan kurikulum berorientasi tujuan yang diterapkan melalui kurikulum 1975, yang menuntut guru menyusun Satuan Pelajaran. Dalam pelaksanaan KBK guru dituntut menyusun Silabus. Untuk dapat melakukan tugas tersebut dituntut kemampuan yang didukung oleh penguasaan ilmu pengetahuan sebagai sumber belajar dan sebagai "ways of learning", mengenal peserta didik dengan karakteristiknya (kemampuan dasar, minat, bakat, dan pola belajarnya), memahami kompetensi yang harus dikuasai peserta didik pada akhir jenjang pendidikan, pada akhir semester, dan pada akhir setiap penglaman belajar, karena tanpa menguasai berbagai pengetahuan dasar tentang ilmu pengetahuan tentang peserta didik, tentang masyarakat dan budaya tempat sekolah beroperasi, teori belajar, berbagai model belajar, dan berbagai model evaluasi, sukar di harapkan guru akan dapat dengan mudah menyesuaikan diri dengan tuntutan baru penyelenggaraan pendidikan nasional yang terus berubah, seperti penerapan KBK. Di dunia kedokteran, sebagai salah satu bidang profesi yang telah lama mapan, para dokter tidak mengenal penataran hanya karena adanya cara baru dalam pengobatan. Tidak lain karena sebagai tenaga profesional mereka telah benar-benar siap dengan ilmu pengetahuan dan teknologi untuk terus mengembangkan kemampuan profesionalnya sesuai dengan tuntutan dunia proiesi kedokteran yang terus berubah.

Dibandingkan dengan dunia kedokteran, dunia keguruan, terutama di Indonesia masih jauh tertinggal. Karena itu tepat sekali kalau berbagai pihak melakukan "Upaya meningkatkan profesionalisrne guru untuk memenuhi tuntutan kurikulum berbasis kompetensi". Karena bagaimanapun juga pelaksanaan KBK menuntut guru yang profesional, sedang tingkat kemampuan profesional guru kita masih beragam.

\section{Program Pengadaan Guru (Pendidik) dan Tenaga Kependidikan}

Dalam bagian terdahulu secara jelas kita memperoleh pengetahuan bahwa guru sebagai jabatan profesional, untuk guru yang memiliki kemampuan profesional penuh perlu memperoleh pendidikan SI plus atau perlu berpendidikan S2, tetapi bukan S2 akademik seperti yang sekarang kita kenal tetapi S2 profesional yang mengutamakan kemampuan mengembangkan, melaksanakan, menilai, mengorganisir, dan memperbaharui program belajar mongajar. Guru dengan tingkat kemampuan profesional yang dcmikian akan selalu mampu mengembangkan dirinya untuk memenuhi tuntutan baru pembaharuan pendidikan seperti penerapan KBK. Tetapi kenyataan yang kita hadapi bukanlah demikian : kualifikasi guru SD kita secara resmi yang tertinggi berpendidikan D II, walaupun ada yang SI dan S2, tetapi SI dan S2-nya kebanyakan akademik bukan profesional disamping masih ada yang belum berpendidikan D II; guru SLTP kita secara resmi disyaratkan D III, walaupun ada yang belum mencapai itu dan ada yang sudah berpendidikan SI, S2, balikan mengikuti program S3. Tetapi umumnya tidak selalu relevan dengan tugas profesionalnya sebagai guru. Demikian juga dengan guru SLTA secara resmi kualifikasi guru SLTA adalah SI, tetapi masih ada yang belum S1, disamping ada yang telah memiliki gelar S2, bahkan mungkin ada yang sedang mengikuti program Doktoi (terutama dikota-kota besar), walaupun umumnya pendidikan lanjutannya tidak selalu terkait dengan tugas profesionalnya sebagai guru. Misainya guru kimia SMA, scharusnya memiliki S1pendidikan kimia, dan S2 pendidikan Kimia, tetapi banyak yang S2-nya bukan pendidikan kimia atau S2 ilmu kimia.

Berangkat dari heterogennya kualifikasi pendidikan dan keniampuan profesional guru dalam upaya meningkaikan kemampuan profesional guru, yaitu : (1) merancang program pembelajaran termasuk menyusun silabus, (2) melaksanakan, memimpin, mengelola, dan menilai program pembelajaran; (3) mendiagnosis masalah dan hambatan yang dihadapi oleh peserta didik dalam mengikuti proses pembelajaran dan menguasai kompetensi yang ditetapkan; dan (4) menyusun dan merancang berbagai pilihan yang harus dikembangkan untuk membantu mereka, tidaklah mudah. Kiranya perlu dikelahui bahwa keempat gugus kemampuan profesional penguasaannya perlu ditunjang oleh pernguasaan berbagai pengetahuan dan teknologi yang terkait dengan : (1) karakteristik peserta didik; 
(2) ilmu pengetahun sebagai obyek belajar dan "ways of learning" atau "mode of inquiry", (3) hakekat tujuan pendidikan dan kompetensi yang harus dicapai dan dikuasai peserta didik; (4) teori belajar umum dan khusus; (5) model-model pembelajaran sesuai dengan bidang studi; (6) teknologi pendidikan; dan (7) sistem dan teknik evaluasi.

Tujuh gugus pengetahuan dan teknologi tersebut ditambah dengan pongetalman dan pemahaman tentang filsafat pendidikan, dasar negara Pancasila, UUD Negara RI 1945, sejarah nasional bangsa dan sistem pendidikan nasional, merupakan pengetahuan yang sehanjsnya dimiliki guru Indonesia yang berderajat profesional. Dengan guru yang pengetahuan dan kemampuan profesionalnya demikian, pembaharuan pendidikan apapun yang dilakukan seperti KBK, tidaK akan dipandang sebagai masalah. Karena guru dengan derajat profesional yang demikian akan dengan mudah menyesuaikan diri dengan tuntutan tugas.

Atas dasar pemahaman saya tentang pengetahuan dan kemampuan profesional garu yang demikianlah yang menjadikan penulis mengusulkan kurikulurn bagi pendidikan prajabatan guru seperti yang tertulis dalam makalah vang telah saya sebut pada pembukaan tulisan ini.

Masalah yang harus dibahas selanjutnya adalah bagaimana kita merancang program pendidikan yang dapat menghasilkan pendidik (guru) dan tenaga kependidikan yang profesional?

Sebelum memasuki jawaban atas pertanyaan "Bagaimana kita merancang program pendidikan yang dapat menghasilkan guru (pendidik) dan tenaga kependidikan yang profesional?", terlebih dahulu saya ingin menyampaikan pandangan saya bahwa tenaga kependidikan, baik tenaga konselor, administrasi pendidikan, teknologi pendidikan ahli kurikulum, dan tenaga kependidikan lainnya seyogyanya berbasis gum profesional. Karena yang akan dikelola, yang akan dibimbing adalah peserta didik dalam situasi kependidikan yang memerlukan pengetahuan dasar dan pengetahun serta kemampuan profesional seorang guru. Inilah pendirian profesional" saya yang telah saya ajukan sejak tahun 1982 yang lalu, yang perlu kita bahas secara profesional pula.

Dalam merancang program pengadaan guru dan tenaga kependidikan lainnya yang profesional yang perlu menguasai delapan gugus pengetahuan dasar akademik profesional dan lima kemampuan profesional, kita perlu menjawab pertanyaanpertanyaan berikut:
(1) bagaimana memilih calon mahasiswa untuk menjadi guru dan tenaga kependidikan lainnya yang profesional ?

(2) bagaimana kurikulum kita rancang dan laksanakan yang relevan?

(3) siapa yang dapat menjadi dosen dan apa peranan dosen?

(4) model pembelajaran manakah yang relavan?

(5) sistem evaluasi yang bagaimana yang perlu diterapkan?

(6) praktek profesional yang bagaimanakah yang perlu dialami oleh calon guru?

(7) fasilitas kependidikan seperti apa yang pcrlu disediakan?

Selanjutnya akan dicoba satu persatu dianalisis ketujuh pertanyaan/masalah yang telah diidentifikasikan.

1. Bagaimanakah kita memilih calon mahasiswa yang secara potensial dapat disiapkan untuk menjadi guru sebagai jabatan profesional

Sebagai pelajar pendidikan saya tidak pernah terkejut mebaca laporan studi tentang tingkat penguasaan guru, baik SD, SMP, maupun SLTA yang sangat rendah terhadap matari pelajaran yang harus dijadikan obyek belajar peserta didik. Tidak lain karena pendidikan pra jabatan guru akhir-akhir ini sangat sukar untuk memperoleh calon mahasiswa dari lulusan SMA yang terbaik. Pada umumnya mereka yang masuk LPTIC adalah mereka yang tidak dapat masuk Fakultas Kedokteran, Fakultas Teknik, Fakultas Ekonomi, bahkan Fakultas yang lain. Padahal pada akhir tahun 1950-an dan permulaan tahun 1960an di Amerika Serikat oleh B. Conant diusulkan bahwa yang dapat diterima menjadi calon guru adalah mereka yang tergolong kelompok $20 \%$ teratas lulusan "High School", yaitu mereka yang selama High School mengambil Kalkulus, Trigonometri, Fisika, dan Bahasa Asing. Di Jerman hanya mereka yang telah melalui Gymnasium (pendidikan 13 tahun) yang dapat memasuki Paedagogische Hochschule (calon guru SD dan Haupth Schule) dan Fakultas Paedagogik (untuk guru Gymnasium). Ini berarti bahwa calon guru adalah mereka yang termasuk kelompok $20 \%$ teratas dari kelompok umurnya.

Kualitas para calon mahasiswa untak pendidikan prajabatan guru yang selama ini; disatu pihak hampir tidak dapat memilih lulusan SMA yang terbaik,- dan dilain pihak proses pembelajarannya yaitu 4 (empat) semester untuk D II, 6 (enam) semester untuk D III, dan 8 (delapan) semester untuk SI, tidak 
ada bedanya dengan program untuk lulusan SMA yang terbaik, tanpa program matrikulasi bagi mereka yang penguasaan pelajaran SMA-nya pas-pasan. Diantara mereka sedikit yang tidak lulus, dengan demikian, tidak heran bahwa penguasaan guru pada umumnya terhadap materi ajar rendah. Akibatnya sangat parah, mulu pendidikan makin menurun, dan ini kurang disadari pengaruhnya pada pembangunan negara bangsa. Padahal negara semaju Amerika Serikat dalam menghadapi persaingan global tidak pernah melupakan pentingnya pendidikan. Untuk itu beberapa pernyataan Gubernur beberapa negara bagian di Amerika Serikat akan dikutipkan berikut ini :

1) "As a nation, and as a stale, we are engaged in protracted economic war of attrition that will not be won with bombers but with blackboard - A war that wilt not be won or lost in the battlefield but in the classroom " (Gov. Richard D Lamm, Colorado)

2) "Education is the fuel that drives the engine of economic growth and job creation in An.erica's modern society " (Gov. Rudy Perpich, Minnesota)

3) "If the state is going to be serious about industrial recruitment, legislatures and citizens must become serious about improving the quality of our educational system " (Gov. Toney Anaya, New Mexico)

4) "I believe that in a global economy. Ohio's ability to overtake our competition is directly linked to the level of our investment in education"

5) "... Excellent schooling requires excellent teachers and principals. Excellent people have self-confidence and self-esteem and expect reasonable otonomy. Therefore, if we want excellent schools, we must give more power to the teachers and principals"

Kelima kutipan ini diambil dari A Nation Prepared: Teachers for the $21^{\text {st }}$ Century. Dalam laporan ini untuk menghadapi abad ke-21, memasuki pendidikan guru disyaratkan telah memiliki "Bachelor Degree in the Arts and Sciences". Sesungguhnya persyaratan ini sudah ditempuh Negara Bagian California pada tahun 1960- an.

Atas dasar pertimbangan profesional tentang guru sebagai jabatan profesional yaitu jabatan yang memerlukan "advance education and special training", agar upaya melahirkan guru yang berderajat profesional dan tenaga kependidikan yang profesional dapat terwujud kita perlu menentukan persyaratan akademik bagi calon mahasiswa LPTK yaitu mereka yang di SMA-nya mengambil Matematika dengan nilai UAN 6, dalam skala 1 - 10,

Untuk itu Pemerintah harus kembali memberi-

kan insentif bagi calon guru dan guru, yaitu memberikan ikatan dinas dan asrama bagi calon guru dan jaminan kesejahteraan bagi guru sejajar dengan profesi lainnya.

\section{Kurikulum untuk pendidikan prajabatan guru yang berderajat profesional}

Merancang dan mengembangkan kurikulum hakekatnya adalah upaya untuk menjawab pertanyaan, "pengalaman belajar dan materi pembelajaran apakah yang harus diikuti dan ditempuh peserta didik, dalam hal ini mahasiswa calon guru, agar setelah mengikuti program pendidikan yang disediakan, dapat dikuasai serangkaian pengetahuan dasar dan kemampuan profesional? Ini berarti bahwa untuk pendidikan calon guru perlu dirancang dua tahap program pendidikan yaitu ; (1) tahap pendidikan akademik profesional; dan (2) tahap pendidikan dan latihan profesional.

Pada tahap pertama. yaitu tahap pendidikan akademik profesional para mahasiswa calon guru mengikuti pendidikan untuk menguasai : (1) pengetahuan dan pemahaman tentang karakteristik peserta didik, baik kognitif, emosional, fisik, dan sosial sesuai dengan tingkat perkembangannya yang terkait dengan jenjang pendidikan; (2) pengetahuan dan pemahaman terhadap ilmu pengetahuan sebagai sumber obyek belajar dan sebagai "ways of knowing"; (3) filsafat pendidikan dan teori pendidikan, yang meliputi tujuan pendidikan nasional dan peranan setiap kegiatan pendidikan untuk mencapai tujuan pendidikan; (4) berbagai teori belajar baik umum, termasuk "social learning theory" dan khusus yang terkait dengan suatu bidang studi dan/atau dengan karakteristik peserta didik; (5) berbagai model pembelajaran yang terkait dengan berbagai bidang studi; (6) teknologi pendidikan; (7) sistem dan teknik evaluasi; dan (8) sejarah dan sistem kenegaraan NKRI sesuai dengan Pancasila dan UUD 1945. Tahap ini dapat ditempuh dalam periode 6 (enam) semester.

Tahap kedua adalah tahap pendidikan dan praktek profesional. Pada tahap ini selama dua semester para mahasiswa belajar menerapkan berbagai pengetahuan dasar akademik profesional yang diperoleh selama enam semester pertama untuk : (1) merencanakan program pembelajaran; (2) melaksanakan program pembelajaran, termasuk mengevaluasi; (3) mendiagnosa berbagai hambatan 
dan masalah yang dihadapi peserta didik; (4) menyempurnakan program pembelajaran berdasarkan umpan balik yang telah dikumpulkan secara sistematik.

Dalam tahap kedua ini calon mahasiswa dua pertiga waktunya berada dalam lingkungan sekolah untuk mengamati, memimpin, dan membimbing proses pembelajaran dibawah supervisi tim dosen profesional.

Setetah melalui program pendidikan yang demikian, seorang mahasiswa yang lulus setelah melalui berbagai evaluasi yang komprehensif dan terus menerus dapat memperoleh "sertifikat" sebagai pengajar.

Mereka yang telah lulus program pendidikan guru profesional inilah yang selanjutnya dapat mengikuti pendidikan pasca sarjana untuk menjadi tenaga kependidikan seperti: bimbingan dan konseling, ahli kurikulum, ahli administrasi pendidikan dan ahli teknologi pendidikan. Dengan demikian tenaga kependidikan yang profesional, dalam pandangan saya, hendaknya adalah mereka yang telah mengikuti pendidikan guru professional dan/atau telah juga berpengalaman sebagai guru profesional, sehingga dapat berperan memberikan bantuan profesional kepada guru untuk terus memperbaiki mutu pendidikan.

Dengan kata lain, tenaga kependidikan yang profesional adalah mereka yang telah memiliki kualifikasi sebagai guru profesional dan melanjutkan studi pasca sarjana atau spesialisasi dibidang-bidang yang telah disebut diatas. Ini sejajar dengan dunia profesi lainnya seperti dokter.

\section{Siapa yang berhak menjadi pengajar dan apa peranan pengajar?}

Kalau untuk menjadi guru, baik SD, SMP, maupun SLTA yang sampai sekarang ditetapkan berkualifikasi minimum D II untuk SD, D III untuk SLTP, dan S1 untuk SLTA, dan dalam pemikiran ini semuanya harus berderajat profesional yaitu minimum SI, sudah sepantasnyalah kalau untuk menjadi pengajar calon guru profesional adalah minimum S2 dengan judisium minimal BAIK atau IPK $\mathrm{B}+$. Dibandingkan dengan persyaratan tenaga pengajar, terutama pada jalur profesorship (Assistant Profesor, Associate Profesor, dan Profesor] di Amerika Serikat yaitu Ph.D dengan judisium minimum sangat memuaskan dan mengalami masa percobaan selama dua tahun, persyaratan minimum S2 dengan IPK minimum $\mathrm{B}+$, kiranya tuntutan minimum S2 bagi dosen, dikemudian hari tidak terlalu idealistis.
Karena gugus mata kuliah pengetahuan dasar akademik profesional meliputi : (1) ilmu pengetahuan sebagai sumber obyek belajar dan ways of knowing; (2) filsafat dan teori pendidikan termasuk filsafat dan teod kurikulum; (3) karakteristik peserta didik; (4) teknologi pendidikaa; (5) teori belajar dan model pembelajaran; (6) sistem evaluasi dan teknik evaluasi; dan (7) sejarah dan sistem sosial budaya Negara Bangsa Indonesia; program pendidikan guru profesional memerlukan para pengajar yang sekaligus berkualifikasi peneliti dari bidang ilmu pengetahuan (1) ilmu-ilmu dasar science, mathematics, engineering science, social sciences/sociology, economy, politics, anthropology, dan bahasa, baik sebagai ilmu murni maupun ilmu kependidikan bidang-bidarig ilmu tersebut; (2) ilmu pendidikan, yang meliputi filsafat pendidikan, teori kurikulum, teknologi pendidikan, sistem dan teknik evaluasi; dan (3) psikologi pendidikan dan psikologi perkembangan, termasuk didalamnya ahli teori belajar.

Peranan para dosen dari setiap bidang ilmu pengetahuan tersebut adalah membimbing dan mendorong para mahasiswa untuk menguasai dan memahami setiap mata kuliah yaag menjadi tanggung jawabnya melelalui proses pembelajaran yang menerapkan empat pilar belajar yaitu : (1) learning to know; (2) learning to do; (3) learning to live together; dan (4) learning to be yang didukung dengan sistem evaluasi sebagai bagian dari proses pendidikan yang dilakukan secara terus menerus, komprehensif, dan obyektif sesuai dengan hakekat ilmu pengetahuan yang dipelajari dan pendekatan empat pilar belajar yang ditempuh.

Sedangkan para pengajar pada tahapan kedua yaitu pendidikan dari praktek profesional diperlukan dosen yang tidak hanya menguasai bidang ilmu yang menjadi tanggung jawabnya melainkan juga mempunyai kepiawaian dalam rnengelola proses pembelajaran. Untuk itu tenaga yang berpengalaman dalam proses pembelajaran diperlukan. Dalam kaitan ini diangkatnya para guru senior yang berpengalaman mengajar menjadi staf pengajar pada tahapan ini sangat diperlukan.

\section{Model Pembelajaran yang Perlu Diterapkan}

Untuk tahap pendidikan untuk menguasai pexigetahuan dasar akademik profesional pendekatan belajarnya scperti telah disinggung adalah pendekatan empat pilar belajar yaitu "learning to know", "learning to do", "learning to live together", dan "learning to be". Melalui pendekatan ini diharapkan para mahasiswa calon guru akan dapat menguasai ilmu pengetahuan sebagai ways of knowing dan penerapannya sehingga dapat diharapkan

Perspektif Ilmu Pendidikan - Vol. 13 Th. VII April 2006 
tumbuhnya minat yang makin mendalam tentang ilmu pengetahuan tersebut dan selanjutnya dapat menimbulkan rasa percaya diri.

Sedangkan untuk tahap kedua pendidikan dan praktek profesional, pendekatan proyek perlu ditempuh, yaitu suatu pendekatan yang menuntut seorang calon guru melakukan kegiatan dari merencanakan dan mengembangkan, melaksanakan, menilai, sampai dengan memperbaiki suatu program pembelajaran dalam suatu bidang mata pelajaran. untuk sesuatu kelompok peserta didik pada jenjang pendidikan tertentu dalam jangka waktu belajar yang jelas.

\section{Sistem Evaluasi yang Perlu Piterapkan}

Dengan diterapkannya model pembelajaran yang menggunakan pendekatan empat pilar belajar, evaluasi yang diterapkan perlu relevan dengan digunakannya empat pilar belajar tersebut. Dengan demikian para calon guru tidak hanya dinilai pemahamannya tentang konsep melainkan dinilai juga: (1) kemampuannya menerapkan "mode of inquiry" suatu disiplin ilmu pengetahuan, seperti melakukan observasi, eksperimen, dan lainnya untuk "learning to know"; (2) kemampuan menerapkan prinsip atau hukum dari suatu bidang ilmu pengetahuan untuk memecahkan masalah untuk "learning to do"; dan (3) kemampuannya untuk bekerjasama dalam bidang ilmu yang sedang dipelajari, untuk "learning to live together".

Sedangkan penilaian dalam tahap kedua benarbenar menilai kinerja seorang calon guru profesional yang meliputi: (1) kemampuan merencanakan dan mengembangkan program pembelajaran; (2) kemampuan mengelola proses pembelajaran; (3) mengembangkan program evaluasi dan melaksanakannya; (4) menganalisis kekuatan, kelemahan, dan masalah dari program yang telah dirancang dan dilaksanakan; dan (5) meyempurnakan program pembelajaran berdasarkan masukan.

\section{Tentang praktek profesional}

Hakekatnya telah diulas pada saat membahas model pembelajaran. Yang penting bahwa pada tahap ini calon guru profesional harus sudah benar-benar bcrada dalam situasi nyata dari proses pembelajaran di kelas dan sekolah dimana setelah lulus mereka akan ditugaskan.

\section{Fasilitas Pendidikan}

Yang jelas agar segala model pembelajaran dapat dilaksanakan, bcrbagai sarana dan prasarana harus tersedia; baik perpustakaan, laboratorium, kebun botani, lapangan olahraga, dan sekolah tempat praktek profesional. Akan lebih ideal lagi kalau mahasiswa calon guru profesional memperoleh fasilitas asrama sebagai bagian integral dari fasilitas pendidikan guru.

\section{Dosen sebagai tenaga akademik/ profesional pada perguruan tinggi, khususnya universitas}

Hal yang menarik untuk dicatat dalam sejarah pendidikan Indonesia adalah bahwa pada saat syarat untuk menjadi guru SD adalah lulusan Sekolah Guru 4 tahun setelah SD (SOB) sampai tahun 1957, untuk menjadi guru SLTP adalah lulusan Sekolah Guru A (enam tahun setelah SD atau tiga tahun setelah SMP) dan guru SLTA adalah lulusan BI dan BII, persyaratan menjadi dosen Perguruan Tinggi, untuk jabatan Asistan Ahli (dosen pemula) adalah Sarjana, atau Doktorandus, Insinyur, atau Sarjana Hukum. Kini setelah untuk menjadi guru SD disyaratkan D II (2 tahun setelah SMA), D III (3 lahun setelah SMA) untuk SLTP, dan SI untuk SLTA, dan tulisan ini menuntut agar semua guru sebagai jabatan profesional harus berpendidikan S1 profesional, persyaratan untuk menjudi dosen pemula (Assisten Ahli) masih tetap SI, walaupun persyaratan yudisiumnya diperberat. Tidak adanya perbedaan yang berarti antara menjadi guru pada pendidikan pra-universitas (SD, SMP, SLTA) dan dosen Perguruan Tinggi, nampaknya mendorong sementara pihak untuk memandang bahwa hakekatnya tidak ada perbedaan yang berarti antara "guru" dengan "dosen" baik dalam peranannya dan persyaratannya. Dalam kaitan ini saya berpendapat lain terutama untuk dosen Universitas. Bukan hanya antara dosen Universitas dan guru berbeda dalam peran dan persyaratannya, tetapi antara dosen Politeknik dan Universitas pun terdapat perbedaan peran dan persyaratannya. Perbedaan itu berangkat dari perbedaan peran kelembagaan antara Sekolah dan Universitas, demikian juga antara Universitas dan Politeknik.

Universitas, di Indonesia, sejak tahun 1962 pada periode Menteri Prof. Iwa Kusuma Sumantri dan diteruskan oleh Prof. Toyib Kadiwijoyo sebagai Menteri Perguruan Tinggi dan Ilmu Pengetahuan dalam pemerintahan Presiden Soekarno telah ditetapkan bukan saja sebagai lembaga pendidik tetapi sebagai lembaga penelitian, dan lembaga penggerak pembangunan. Suatu doktrin yang telah ditempuh oleh Presiden Abraham Lincoln pada tahun 1862, melalui "Morrii Act" tentang "Uuidgrant 
Movement" yang mewajibkan Universitas Negeri sebagai lembaga pendidikan, lembaga penelitian, dan penggerak pembangunan nasional melalui proses percepatan industrialisasi dan manufacturing. Sejak saat itu Universitas di Indonesia mengenal Tri Dharma Pcrguruan Tinggi yaitu Pendidikan, Penelitian, dan Pengabdian kepada masyarakat. Atas dasar landasan ini pula nampaknya mengapa dalam Program Pembangunan Berencana 8 tahun (1961 - 1969) untuk setiap provinsi sekurang-kurangnya didirikan sebuah Universitas Negeri yang berfungsi untuk mempercepat proses pembangunan nasional.

Sesungguhnya didudukkannya Universitas tidak hanya sebagai lembaga pendidikan tetapi sebagai lembaga riset sudah berlangsung sejak tahun 1809 dengan tokohnya Von Humbelt (Jerman) yang menjadikan Universitas sebagai lembaga pendidikan dan lembaga riset. Sejak saat itu universitas menjadi tulang punggung pengembangan Iptek yang menunjang perkembangan peradaban sampai era globalisasi sekarang ini. Sejak tahun 1960-an sampai dengan tahun 2005 ini dunia meyakini betapa strategisaya peranan. universitas dalani proses kemajuan masyarakat. Beberapa kutipan berikut ingin menunjukkan bukti dan persepsi tentang peranan universitas dalam pembangunan peradaban, terutama pada era globalisasi ini.

Pada tahun 1963, Clark Kerr Presiden University of California menyatakan :

"The basic reality, for the university is the widespread recognition that the new knowledge is the most important factor in economic and social growth. We are just now perceiving (hat the universities invisible product, knowledge, may he most powerful single element in our culture, affecting the rise and fall of professions and even of social classes of regions and even of nation."

Pada tahun 1996, Komisi International Pendidikan untuk Abad ke-21, memberikan pandangan tentang peranan universitas dalam kalimat berikut:

"Nowhere is the universities responsibility for the development of the society as a whole more acute than in developing countries, where research done in the institutions of higher learning plays a pivotal role in providing the basis for development programms, policy formulation and the training of middle and higher level human resources."

Pada tahun 1997 Sheila Slaughter mengikuti pandangan seorang pemenang hadiah Nobel tahun
1976 tentang peranan universitas di era "post industrial" dalain kalimat berikut:

"As many inventions of industrial revolution were made by non schoped amateurs and inventions as by framed scientist (Ben David 1965, Noble 1976); most of the discoveries of the current technological revolutionwerw made by persons with advanced degree. The post-industrial technological revolution depend on universities. Universities provide the necessary for the increasing members of profesionals employed by corporation to invent and innovate with regard to sophisticated technologies and product to increasing numbers of cases universities on the sites where new technologies and products are developed, after in partnership with business through funding provided in part by the state."

Pada tahun 2005 majalah mingguan The Economist dalain survey tentang perguruan tinggi yang diberi judul "The brain business" menyampaikan pandangannya tentang kedudukan Universitas dalam era "knowledge economy" dalam kalimat berikut.

"The world is in the grips of "a soft revolution" in which knowledge is replacing physical resources as the main driver of economic growth. The OECD calculates that between 1985 and 1997 ihn contribution of knowledge based industries to total value added increase from $51 \%$ to $59 \%$ in Germany and from $45 \%$ to $51 \%$ in Britain. The best companies arc now devoting at least a third of their investment to knowledge intensive intangibles such as $R \mathcal{E} D$, licensing and marketing Universities are among the most important engines of the knowledge economy"

Dan serangkaian kutipan tentang peranan yang diharapkan dari universitas sebagai lembaga pendidikan, lembaga penelitian, dan agen pembangunan masyarakat dari abad ke-19 sampai tahun 2005, dapat muncul pertanyaan berikut : (1) seberapa jauh universitas di Indonesia telah menjadi sumber "knowledge" bagi pembangunan masyarakat negara bangsa Indonesia khususnya, dan peradaban dunia umumnya ?, (2) kalau belum mengapa Universitas di Indonesia belum dapat berperan seperti yang diharapkan oleh keberadaan Universitas dalam suatu negara?; dan (3) bagaimana kita dapat menjadikan Universitas di Indonesia dapat melaksanakan peranannya sebagaimana universitasuniversitas di negara maju, terutama Eropa Barat dan Amerika Utara (khususnya Amerika Serikat)?

Perspektif Ilmu Pendidikan - Vol. 13 Th. VII April 2006 
Nampaknya kita belum dapat memberikan jawaban yang positif terhadap pertanyaan pertama. Serangkaian krisis yang dihadapi bangsa Indonesia, baik krsis politik, krisis ekonomi, krisis multidimensi dan krisis kepercayaan yang melanda bangsa Indonesia tanpa adanya strategi komprehensif yang untuk mengatasinya baik jangka panjang, menengah, dan pendek menunjukan betapa kehidupan bangsa ini belum cerdas seperti yang diharapkan oleh para pendiri Republik. Salah satu lembaga sosial budaya yang keberadaannya dapat berpartisipasi dalam upaya mencerdaskan kehidupan bangsa adalah Universitas.

Terhadap pertanyaan kedua "mengapa universitas di Indonesia yang telah berdiri hampir satu abad belum juga mampu mendukung proses membangun bangsa yang cerdas kehidupannya?" Jawabnya secara umum adalah bahwa bila dibandingkan dengan universitas yang dinegaranya peranannya sangat dominan seperti yang diakui oleh Clark Kerr, Komisi International untuk Pendidikan abad ke-21, Ben David, hasil survei "The Economist", Universitas di Indonesia tidak memperoleh dukungan dana, sarana, dan prasarana yang memungkinkan universitas dapat berperan sebagai lembaga pendidikan dan lembaga riset. Bandingkan unit cost per mahasiswa per tahun, kalau di Amerika Serikat 22.000 US Dollar, Eropa sekitar 10.000 US dollar (tahun 2001), berapa unit cost per mahasiswa per tahun di Indonesia? Kalau setiap dosen di Amerika Serikat dan Eropa memiliki ruang kerja dan laboratorium tersendiri, bagaimana dengan di Indonesia. Keseluruhan dana untuk mendukung penyelenggaraan universitas di Amerika Serikat mencapai 2,5\% GDP, di Indonesia untuk mendukung penyelenggaraan pendidikan nasional belum mencapai 1\% GDP. Dari sekilas perbandingan ini, kenyataan belum berperannya secara efektif universitas di Indonesia dalam menunjang proses pencerdasan kehidupan bangsa masalahnya bukan terletak pada universitas itu sendiri, tetapi terutama adalah kemauan politik penyelenggara negara untuk mendudukkan penyelenggaraan universitas sebagai "investasi" masa depan yang tidak dapat ditawar (to be or not to be).

Dari ulasan terhadap pertanyaan kedua, jelaslah bahwa untuk menjawab pertanyaan ketiga, tentang bagaimana kita dapat menjadikan universitas di Indonesia dapat berperan sebagai penghasil IPTEK, disamping penghasil teknologi, peneliti, penemu, dan inovator yang handal perlu dukungan dana yang berarti bagi tersedianya sarana dan prasarana dan tenaga dosen yang berkualitas dan berdedikasi kepada kemajuan ilmu pengetahuan dan teknologi bagi kemajuan bangsa dan kemanusiaan. Dengan demikian jelas bahwa universitas sebagai Iembaga pendidikan dan lembaga riset serta agen pembangunan masyarakat haruslah benar-benar " $A$ Center of Excellent" yaitu tempat bertemu "excellent scholars" dan "excellent young generation". Ini hakekat inti yang membedakan universitas dan pendidikan yang lain. Di Amerika Serikat, pada tahun 1960-an, Negara Bagian California yang dapat menjadi mahasiswa di University of California adalah the top $10 \%$ lulusan sekolah menengah, di bawah kelompok itu dapat masuk State College, Junior College dan Community College. Mereka adalah pelajar sekolah menengah yang menempuh mata pelajaran kalkulus, trigonometri, dan fisika. Di Jerman hanya mereka yang mengikuti Gymnasium yang lamanya 13 tahun yang syarat utamanya adalah matematika dan bahasa Jerman. Untuk itu dosen pada universitas syaratnya, adalah Ph. D. "holder". Karena itu dalam upaya menjadikan universitas benar-benar "Center of Excellent" pada bagian tentang pengajar untuk calon dosen profesional saya usulkan persyaratannya adalah lulusan S2 dengan yudisium baik ke atas. Dalam kaitan dengan dosen universitas seyogyanya kita menuju ke persyaratan lulusan Doktor, karena dosen pada universitas tugas utamanya bukan mengajar dalam pengertian memberikan penjelasan tentang ilmu yang dipelajari melainkan terutama menantang para mahasiswa untuk berpikir, berimajinasi, mempertanyakan, meneliti sehingga sarjana lulusan universitas berpotensi menjadi penemu dan inovator dalam bidangnya, dengan melakukan penelitian. Karena itu syarat utarna untuk menjadi dosen universitas seharusnya adalah "ilmuwan" yaitu sarjana yang benar menguasai ilmunya dan mampu mengembangkan ilmu pengetahuannya.

Pada saat sekarang kita sukar untuk menetapkan syarat lulusan program Doktor untuk menjadi dosen Universitas, karena di Indonesia, sangat jarang seorang mahasiswa mengikuti program pendidikan secara berkesinambungan tanpa putus dari SI sampai Doktor. Karena itu harus ada upaya untuk dapat menarik lulusan SI yang "excellent" untuk disiapkan menjadi dosen universitas dengan diberi dukungan beasiswa untuk mencapai gelar doktor. Dosen-dosen yang sekarang masih berkualifikasi SI dan S2 diberi beasiswa untuk menempuh program Pasca Sarjana sampai memperoleh derajat doktor. 
Dari serangkaian ulasan pada bagian tiga ini jelaslah bahwa dosen universitas secara kualitatif peran dan tanggung jawabnya berbeda dengan guru. Selanjutnya apakah implikasi pendanaan bagi pengadaan guru yang berderajat profesional dan dosen yang berderajat ilmuwan? Bagian berikut akan mencoba menyorotinya.

\section{Implikasi keuangan dari guru sebagai jabatau profesional dan dosen universitas sebagai ilmuwan pengajar}

\section{Implikasi Keuangan dari Kedudukan Guru sebagai Jabatan Profesional}

Implikasi keuangan dari ditetapkannya guru sebagai jabatan profesional akan meliputi tahap : (1) pembiayaan pendidikan pra-jabatan guru, (2) pembinaan guru dalam jabatan; (3) pelaksanaan guru sebagai pendidik profesional.

1.1. Pada tahap pendidikan pra-jabatan guru diperlukan:

a. dana modal untuk membangun berbagai sarana dan prasarana seperti laboratorium, lapangan olah raga, bengkel kerja, ruang rnusik, dan asraraa mahasiswa calon guru;

b. dana ikatan dinas bagi calon guru berbakat dari keluatga kurang mampu;

c. dana operasional penyelenggaraan pendidikan dan latihan profesional

1.2. Pada tahap pembinaan guru dalam jabatan.

Mengingat sebagian besar guru masih berkualifikasi dibawah profesional seperti lulus

D II dan D III. Harus tersedia dana untuk mendukung upaya meningkatkan kemampuan profesional mereka.

1.3. Pada tahap pelaksanaan tugas guru profesional Dengan menetapkan guru sebagai jabatan profesional berarti tugas guru tidak lagi hanya memberikan pelajaran di kelas pada jam pelajaran yang telah dijadwal. Tugas guru sebagai yang telah diulas meliputi : (1) merencanakan program pembelajaran; (2) mengelola proses pembelajaran; (3) menilai proses hasil belajar; (4) mendiagnosis berbagai masalah yang ditemukan dalam proses pembelajaran; dan (5) memperbaiki program pembelajaran dan memberikan bantuan dan bimbingan kepada peserta didik diluar jam pelajaran.

Kita tidak dapat mengharapkan seorang guru profesional untuk melaksanakan kelima fungsi profesional tersebut dalam waktu, seperti yang sekarang umumnya berlangsung, yaitu selama berlangsungnya proses belajar mengajar di sekolah. Untuk itu guru harus bekerja dari jam 07.00 sampai 13.00 ditambah sekurangkurangnya dua jam setclah program pembelajaran di kelas usai. Ini berarti guru tidak dimungkinkan untuk mencari penghasilan tambahan. Untuk itulah penghasilan guru harus memungkinkan guru dapat hidup secara layak sebagai tenaga profesional. Seberapa besar penghasilan minimal seorang tenaga guru profesional? Ini perlu dihitung dengan cermat paling tidak dapat mendukung kehidupan guru dan keluarganya baik untuk keperluan sandang dan pangan, perumahan, transportasi, kesehatan, pendidikan, rekreasi dan tabungan untuk masa depan.

\section{Implikasi keuangan bggi kedudukan dosen universitas sebagai ilmuwan pengajar}

Dengan memahami kedudukan dosen sebagai ilmuwan pengajar di "center of excellent" dapat diidentifikasikan beberapa dimensi yang menuntut pembiayaan :

2.1. Pada tahap penyiapun calon dosen

Karena jabatan dosen idealnya dipersyaratkan berpendidikan doktor (S3), pertama perlu disediakan dana untuk memberi beasiswa kepada lulusan SI yang excellent yang bersedia menjadi dosen untuk melanjutkan pendidikannya ke program Pasca Sarjana sampai memperoleh gelar doktor. Beasiswa juga perlu diberikan kepada dosen yang belum bergelar doktor untuk mengikuti program pasca sarjana untak dapat mencapai gelar doktor.

2.2. Pada tahap pelaksanaan tugas

Seorang dosen universitas sebagai ilmuwan pengajar tugasnya tidak hanya memberi kuliah tetapi melakukan riset untuk mendukung bahan kuliahnya sehingga dapat menantang para mahasiswa mampu melakukan riset untuk kemajuan ilmu pengetahuan dan pengembangan IPTEK. Karena itu dosen dengan tugas yang demikian tidak mungkin hanya datang ke kampus kalau memberi kuliah, dan tidak ada waktu serta tempat untuk dapat berdiskusi dengan mahasiswa diluar jam kuliah, apalagi merenungkan masalah keilmuwan dan melakukan riset. Untuk itu setiap universitas sesungguhnya tidak ada istilah "Research University" karena kalau sebuah lembaga perguruan tinggi berstatus universitas dengan sendirinya dia harus berfungsi juga sebagai 
lembaga riset - haruslah memberikan ruang kerja untuk dosen dan laboratorium bagi dosen (Guru Besar) bidang ilmu eksakta. Dengan demikian dosen wajib bekerja dikampus tidak hanya kalau memberi kuliah. Agar kita dapat mewajibkan dosen bekerja demikian, penghasilan dosen harus dapat memenuhi kebutuhan: (1) sandang dan pangan; (2) perumahan yang memadai untuk seorang dosen (jaman Presiden Sukarno minimum bangunan $250 \mathrm{~m}^{2}$; (3) transport; (4) kesehatan dan pendidikan; (5) membeli buku dan majalah ilmiah; (6) keperluan riset; dan (7) tabungan untuk masa depan. Demikianlah identifikasi dimensi yang perlu dibiayai sebagai konsekuensi penetapan guru sebagai jabatan profesional dan dosen universitas sebagai ilmuwan pengajar akan nampak betapa benarnya pasal 31 ayat (4) UUD 1945 yang menetapkan agar disediakan dana untuk menunjang keperluan menyalenggarakan pendidikan nasional sekurang-kurangnya $20 \%$ APBN dan 20\% APBD. Ini bukan hanya 20\% tetapi sekurang-kurangnya $20 \%$. Di negeri Belanda 37\% APBN atau 7\% GDP. Sekaiang ada rencana DPR dan Pemerintah untuk mencapai $20 \%$ pada tahun 2009, padahal seharusnya mulai dari 20\% APBN untuk terus ditingkatkan. Kalau ketentuan UUD 1945 dilaksanakan segala implikasi pembaharuan pendidikan akan dapat dilaksanakan dan cita-cita menoerdaskan kehidupan bangsa dan memajukan kebudayaan nasional akan dapat terwujud.

\section{Beberapa Catatan Penutup}

1. Dalam rangka melaksanakan amanat UUD 1945 yaitu menyelenggarakan Satu Sistem Pendidikan Nasional untuk mencerdaskan kehidupan bangsa dan memajukan kebudayaan nasional berbagai ketentuan dalam UU No. 20 Tahun 2003 tentang Sistem Pendidikan Nasional, terutama pasal 5 ayat (1) dan pasai 12 ayat (1) yang tertulis :

"Setiap warga negara berhak memperoleh pendidikan yang bermutu" (pasal 5 ayat [ 1 ]); dan "Setiap peserta didik berhak memperoleh pendidikan yang sesuai dengan minat, bakat, dan kemampuannya".

Keharusan menjadikan pekerjaan guru sebagai jabatan profesional yaitu suatu jabatan yang memerlukan pendidikan lanjut dan latihan khusus, tidak dapat ditunda lagi.
2. Dalam upaya menyiapkan guru yang berderajat profesional, persyaratan untuk dapat diterima sebagai mahasiswa calon guru haruslah dari mereka yang tergolong dalam kelompok $20 \%$ teratas yang lulus SMA dengan nilai Matematika minimal 6.

3. Guru sebagai jabatan profesional untuk jenjang apapun, SD, SLTP, SLTA, memerlukan pendidikan prajabatan guru serendahrendabnya SI

4. Program pendidikan prajabatan guru profesional harus mengantarkan para mahasiswa calon guru untuk menguasai seperangkat pengetahuan akademik profe-sional selama 6 (enam) semester dan pendidik-an dan praktek profesional selama dua semester.

5. Agar tenaga kependidikan benar-benar mampu memberikan bantuan profesional kepada guru pada khususnya dan program pembelajaran pada umumnya, jabatan tenaga kependidikan, seperti bimbingan konseling, ahli kurikulum, administrasi pendidikan, dan teknologi pendidikan merupakan jabatan untuk mereka yang memiliki pendidikan dasar sebagai guru profesional ditambah pendidikan pasca sarjana dan/atau spesialisasi dibidangnya.

6. Program pendidikan prajabatan guru dapat mencapai sasaran pendekatan belajar yang bertumpu pada empat pilar belajar untuk tahap pendidikan akademik profesional, dan pendekatan belajar proyek untuk tahap pendidikan dan latihan profesional perlu diterapkan. Khusus untuk program peadidikan tahap pendidikan dan praktek profesional para mahasiswa calon guru harus berada dalam situasi belajar-mengajar di kelas, baik sebagai pengamat maupun sebagai pergelola proses pembelajaran yang berada dalam supervisi tim dosen yang ditugaskan.

7. Sejalan dengan upaya menetapkan guru sebagai jabatan profesional, yang pendidikan minimalnya adalah SI, sudah selayaknya kalau pengajar pada Universitas/Perguruan Tinggi penyelenggara pendidikan pra-jabatan guru berpendidikan minimal S2 dengan kualifikasi yang memadai.

8. Segala upaya untuk menjadikan pendidikan pra-jabatan guru akan berhasil secara efektif sesuai dengan pemikiran yang dibahas apabila segala sarana dan prasarana yang meliputi: perpustakaan, laboratorium, bengkel kerja, ruang kesenian dan musik, kebun botani/ 
zoologi, lapangan olahraga, dan asrama dipenuhi. Disamping itu berbagai inscntif untuk menarik putra-putri terbaik bangsa menjadi guru perlu diadakan, baik ikatan dinas, penempatan dan pembinaan guru, dan jaminan kesejahteraan bagi guru yang kompetitif dengan jabatan profesional lainnya.

9. Agar Universitas di Indonesia benar-benar dapat menjadi lembaga pendidikan, lembaga riset, dan lembaga penggerak pembangunan, Pemerintah harus memberikan dukungan dana yang berarti dengan tenaga dosen yang adalah ilmuwan pengajar yang suatu saat harus minimal bergelar doktor.

10. Agar guru profesional benar-benar dapat melaksanakan tugas dan fungsinya sebagai pendidik profesional yang merancang, mengembangkan, melaksanakan, menilai, dan mendiagnosa berbagai masalah pendidikan yang dihadapi peserta didik, jaminan kesejahteraan yang meliputi; sandang, pangan, dan papan, transportasi, kesehatan, pendidikan, dan tabungan untuk hari tua perlu diberikan sesuai dengan martabatnya sebagai tenaga profesional.

11. Agar putra-putri terbaik bangsa yang berkiprah di bidang ilmu pengetahuan dan teknologi dapat ditarik menjadi dosen, perlu diberikan jaminan kesejahteraan yang meliputi: sandang, pangan, perumahan, transportasi, kesehatan, pendidikan, fasilitas kerja seorang ilmuwan, dana untuk riset dan membeli buku, serta tabungan untuk hari tua.

\section{DAFTAR PUSTAKA}

Carnegie Forum on Education and Economy. (1986) A nation prepared: Teachers for the 21st century. The Report of The Taskforce on Teaching as a Profession.

Delors, J., et. al. (1998). Learning: The treasure within. Report to Unesco of the International Commision of Education for the Twenty First Century. Paris: Unesco.

Kerr, C. (1963). The uses of university. Harper Torchbooks.

Slaughter, S. , \& Leslie, L. (1997). Academic capitalism: Politics, policies, and the entreprenural university. Baltimore: The John Hopkins University Press.

The Brain Bussiness. (2005, September). Report of A Survey of Higher Education. The Economist ed. Sept 10th, 2005.

\section{KETERANGAN PENULIS}

Prof. Dr. Soedijarto, MA, adalah guru besar Universitas Negeri Jakarta dan saat ini juga menjabat Ketua Umum ISPI, anggota DRN, anggota BP MPRRI, Ketua KINAPS, Ketua Basnas dan Penasehat PB PGRI. Salah satu bukunya yang diterbitkan Balai Pustaka (2003) berjudul Pendidikan Nasional Sebagai Transformasi Budaya. 